\title{
MAKALAH PASAR DAN PEMASARAN
}

Dosen Pengampu

Dra.Hj.Nuraeni Gani,MM

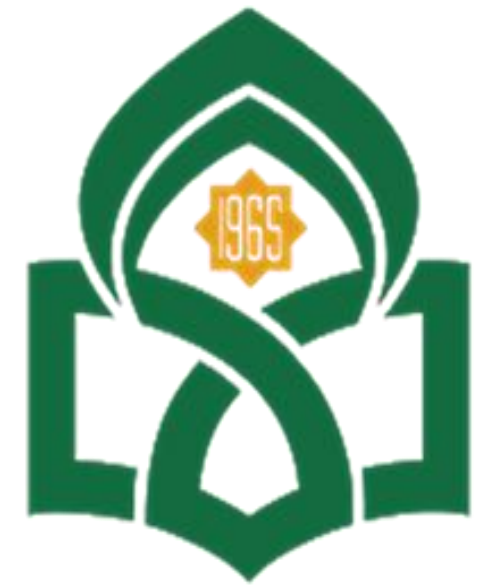

UNIVERSITAS ISLAM NEGERI

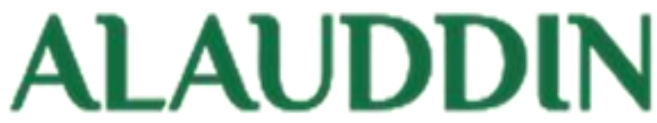

M A K A S S A R

DAHLIA

90500120006

PERBANKAN SYARIAH

FAKULTAS EKONOMI DAN BISNIS ISLAM

UNIVERSITAS ISLAM NEGERI ALAUDDIN MAKASSAR

TAHUN 2020/2021 


\section{KATA PENGANTAR}

Segala puji bagi Allah yang telah menolong hamba-Nya dalam menyelesaikan makalah ini dengan penuh kemudahan. Tanpa pertolongan-Nya mungkin kami tidak akan sanggup menyelesaikan makalah ini dengan baik.

Makalah ini di susun oleh penyusun dengan berbagai rintangan. Baik itu yang datang dari diri penyusun maupun yang datang dari luar. Namun dengan penuh kesabaran dan terutama pertolongan dari Allah akhirnya makalah ini dapat terselesaikan. Makalah ini memuat tentang PASAR DAN PEMASARAN". Penyusun juga mengucapkan terima kasih kepada dosen pembimbing, teman-teman, dan semua pihak yang terlibat dalam penyusunan makalah ini, sehinggga makalah ini dapat terselesaikan dengan baik.

Semoga makalah ini dapat memberikan wawasan yang lebih luas kepada pembaca.Kami menyadari masih banyak kekurangan dan kesalahan dalam penyusunan makalah ini. Oleh karena itu, kami mengharapkan kritik dan sarannya guna perbaikan di kemudian hari. Terimakasih

Takalar, 17 Desember 2021 


\section{DAFTAR ISI}

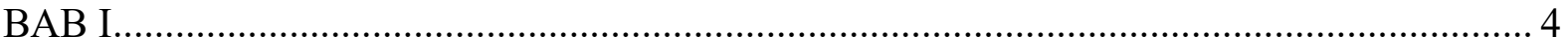

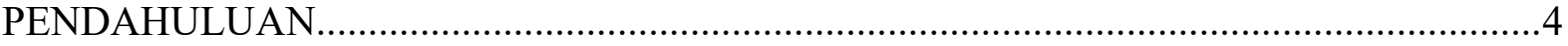

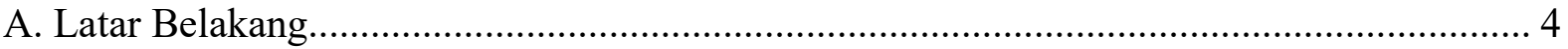

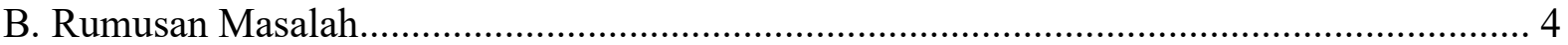

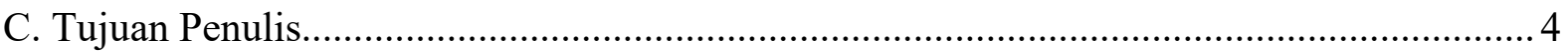

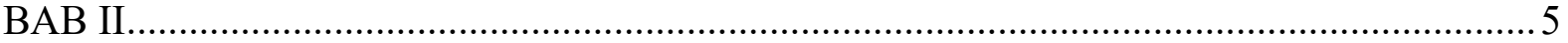

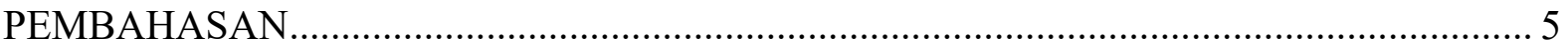

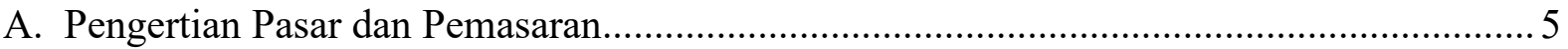

1. Fungsi Pasar........................................................................... Error! Bookmark not defined.

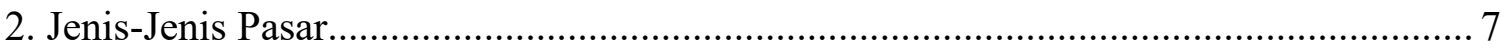

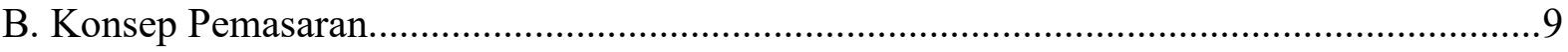

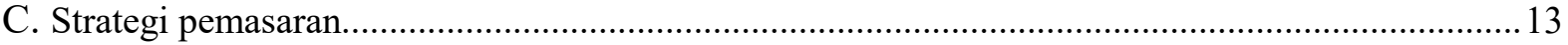

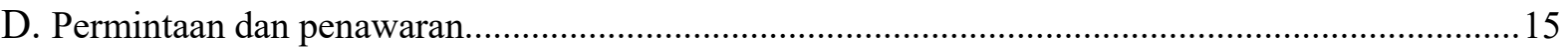

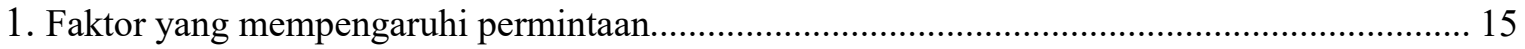

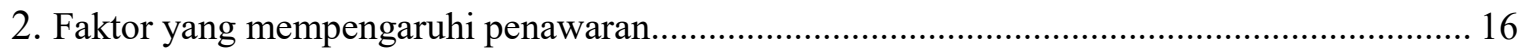

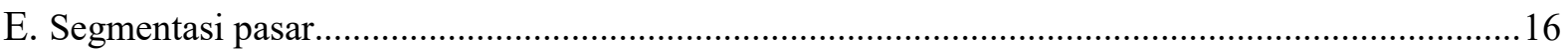

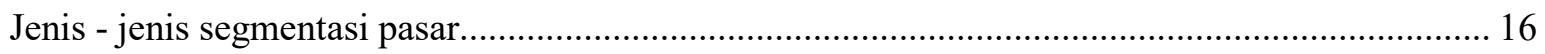

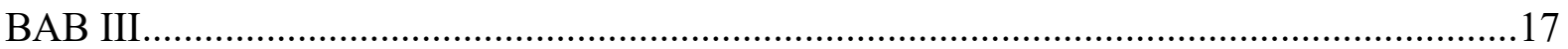

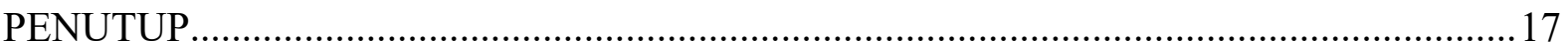

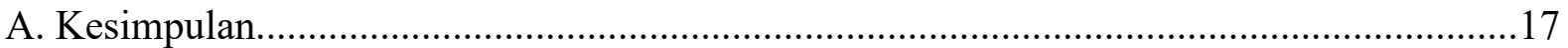

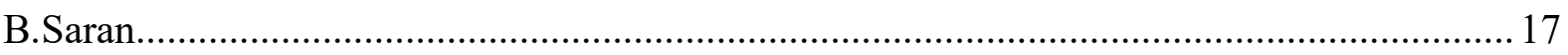

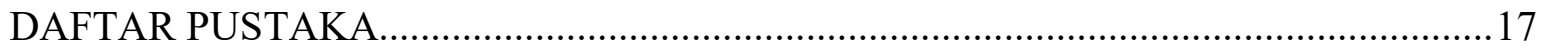




\section{BAB I \\ PENDAHULUAN}

\section{A. Latar Belakang}

Pasar adalah salah satu sarana pendukung untuk memenuhi kebutuhan hidup manusia. Selain itu pasar juga dapat diartikan suatu tempat atau proses interaksi antara permintaan (pembeli) dan penawaran (penjual) dari suatu barang atau jasa tertentu, sehingga akhirnya dapat menetapkan harga keseimbangan (harga pasar) dan jumlah yang diperdagangkan secara singkat . pasar juga dapat diartikan sebagai suatu tempat terjadinya transaksi jual beli antara pedagang dan pembeli. Suatu pasar bisa berkembang jika letaknya strategis. Pemasaran dalam perusahaan industri yang menghasilkan barang maupun jasa sangat penting keberadaan dan juga kelangsungan hidupnya. Pemasaran merupakan bagian dari manajeman perusahaan dan juga salah satu faktor yang sangat penting, karena pemasaran akan mempengaruhi secara langsung terhadap kelancaran maupun keberhasilan perusahaan dalam mencapai tujuannya.

\section{B. Rumusan Masalah}

Berdasarkan latar belakang dalam makalah Manajemen Pasar dan Pemasaran di atas, penulis dapat mengambil Rumusan Masalah sebgai berikut :

a) Apa yang dimaksud dengan Pasar dan Pemasaran?

b) Apa saja fungsi dari Pasar serta jenis-jenis Pasar?

c) Bagaimana konsep Pemasaran?

d) Bagaimanakah strategi Pemasaran?

e) Apa yang dimaksud dengan Permintaan dan Penawaran?

f) Apa yang dimaksud dengan Segmentasi Pasar dan apa saja manfaatnya?

\section{Tujuan Penulis}

Tujuan dalam penulisan Makalah "Pasar dan Pemasaran" adalah sebagai berikut :

a) Untuk mengetahui definisi dari Pasar dan Pemasaran

b) Untuk mengetahui Fungsi dan Jenis-jenis Pasar

c) Untuk mengetahui Konsep Pemasaran

d) Untuk mengetahui Strategi Pemasaran 
e) Mengetahui definisi dari Permintaan dan Penawaran

f) Mengetahui Segmentasi Pasar beserta Manfaatnya

\section{BAB II}

\section{PEMBAHASAN}

\section{A. Pengertian Pasar dan Pemasaran}

\section{- Pasar}

Pasar secara umum dimaksud sebagai tempat penjual menawarkan barang ataupun jasa sesuai taksiran harga penjual dan pembeli memperoleh benda ataupun jasa cocok dengan taksiran harga pembeli. Pasar pula bisa dimaksud sebagai tempat bertemunya para penjual serta pembeli buat melaksanakan transaksi.

Pasar tradisional ialah tempat bertemunya penjual serta pembeli dan diisyarati dengan terdapatnya transaksi penjual serta pembeli secara langsung, bangunan umumnya terdiri dari kios- kios ataupun gerai, los, serta dasaran terbuka yang dibuka oleh penjual ataupun suatu pengelola pasar. Pasar modern merupakan pasar yang dikelola oleh manajemen modern, biasanya ada di perkotaan, sebagai penyedia benda serta jasa dengan kualitas serta pelayanan yang baik kepada konsumen. Di pasar modern, penjual serta pembeli tidak bertransaksi secara langsung serta tidak terdapat negosiasi melainkan pembeli memandang label harga yang tercantum dalam barang( barcode), terletak dalam bangunan, serta pelayanannya dicoba secara mandiri( swalayan) ataupun dilayani oleh pramuniaga. Pasar modern antara lain supermarket, mall, mini market, shopping centre, department store, serta sebagainya. Benda yang di jual memiliki variasi tipe yang bermacam- macam serta memiliki mutu yang relatif lebih terjamin sebab lewat penyeleksian terlebih dulu secara ketat.

\section{- Peranan Pasar}
a. Peranan pasar bagi produsen

- Sebagai tempat untuk mempromosikan barang.

- Sebagai tempat untuk menjual hasil produksi.

- Sebagai tempat untuk memperoleh bahan produksi.

b. Peranan pasar bagi konsumen

- Memudahkan konsumen untuk mendapatkan barang kebutuhan

- Sebagai tempat bagi konsumen untuk menawarkan sumber daya yang dimiliki

c. Peranan pasar bagi pemerintah

- Sebagai penunjang kelancaran pembangunan 
- Sebagai sumber pendapatan Negara

- Pemasaran

Pemasaran merupakan salah satu aktivitas pokok yang perlu dicoba oleh perusahaan baik itu perusahaan barang ataupun jasa dalam upaya untuk mempertahankan kelangsungan hidup usahanya. Perihal tersebut diakibatkan sebab pemasaran ialah salah satu aktivitas perusahaan, di mana secara langsung berhubungan dengan konsumen. Hingga aktivitas pemasaran bisa dimaksud selaku aktivitas manusia yang berlangsung dalam kaitannya dengan pasar.

Kotler( 2001) mengemukakan definisi Pemasaran berarti bekerja dengan pasar sasaran guna mewujudkan pertukaran yang potensial dengan maksud memuaskan kebutuhan serta keinginan manusia. Sehingga bisa dikatakan jika keberhasilan pemasaran ialah kunci kesuksesan dari suatu perusahaan.

Bagi Stanton( 2001), definisi pemasaran merupakan sesuatu sistem totalitas dari kegiatankegiatan bisnis yang diperuntukan untuk merencanakan, menentukan harga, mempromosikan serta mendistribusikan barang ataupun jasa yang memuaskan kebutuhan baik kepada pembeli yang terdapat ataupun pembeli potensial.

\section{Pasar dan Pemasaran}

Dalam kehidupan tiap hari, pasar pastinya sangat berarti. Sebab pasar mempunyai fungsi sebagai berikut:

- Pembentukan nilai harga.

Pasar berperan buat pembuatan harga( nilai) sebab pasar ialah tempat bertemunya penjual serta pembeli yang setelah itu silih menawar serta akhirnya membuat konvensi sesuatu harga. Harga ataupun nilai ini ialah sesuatu hasil dariproses jual beli yang dicoba di pasar.

- Pendistribusian

Pasar memudahkan produsen buat mendistribusikan benda dengan para konsumen secara langsung. Pendistribusian benda dari produsen ke consume hendak berjalan mudah apabila pasar berperan dengan baik.

- Promosi

Pasar ialah tempat yang sangat sesuai untuk produsen buat memperkenalkan

( mempromosikan) produk- produknya kepada konsumen. Sebab pasar hendak selalu didatangi oleh banyak orang, walaupun tidak diundang. 


\section{Jenis-Jenis Pasar}

\section{a. Jenis-jenis pasar menurut fisiknya}

- Pasar konkret (pasar nyata) adalah tempat pertemuan antara pembeli dan penjual melakukan transaksi secara langsung. Barang yang diperjualbelikan juga tersedia di pasar. Contohnya, pasar sayuran, buah-buahan, dan pasar tradisional.

- Pasar abstrak (pasar tidak nyata) adalah terjadinya transaksi antara penjual dan pembeli hanya melalui telepon, internet, dan lain-lain berdasarkan contoh barang. Contohnya telemarket dan pasar modal.

\section{b. Jenis pasar menurut bentuk atau organisasi pasar}

1) Pasar persaingan sempurna( perfect competition market), merupakan pasar yang ada banyak penjual serta pembeli sehingga harga tidak dapat didetetapkan oleh tiap- tiap penjual/ pembeli.

Ciri- cirinya:

1. Pengetahuan penjual serta pembeli sempurna

2. Penjual serta pembeli leluasa keluar masuk pasar

3. Penjual serta pembeli banyak

4. Benda yang diperjualbelikan bertabiat homogeny

2) Pasar persaingan tidak sempurna( imperfect competition market), merupakan pasar di mana jumlah pembeli lebih banyak daripada jumlah penjual.

Ciri- ciri:

1. Pengetahuan pembeli tentang pasar terbatas

2. Ada hambatan nutuk memasuki pasar

3. Jumlah penjual sedikit

4. Barang yang diperjualbelikan heterogen

- Pasar persaingan tidak sempurna dibedakan jadi:

a) Pasar dominasi, merupakan pasar yang seluruhnya dipahami satu penjual. Contoh: PLN memahami listrik di Indonesia.

Ciri- ciri:

1. Ada satu penjual serta banyak pembeli.

2. Harga didetetapkan oleh penjual.

3. Tidak terdapat barang lain yang bisa mengambil alih barang yang diperjualbelikan.

4. Terdapat rintangan untuk penjual baru yang mau masuk.

\section{- Pemicu munculnya pasar monopoli:}


1. Diresmikan oleh pemerintah bersumber pada undang- undang

2. Penggabungan dari bermacam perusahaan

3. Terdapatnya hak paten atas hasil karya

- Hambatan yang terjalin pada pasar monopoli:

1. Penetapan harga serendah mungkin

2. Terdapatnya kepemilikan terhadap hak paten/ hak cipta serta hak eksklusif

3. Pengawasan yang ketat terhadap agen serta distributor

4. Terdapatnya skala hemat yang sangat besar

5. Mempunyai sumber daya yang unik

b) Pasar duopoli, ialah pasar yang dikuasai oleh 2 penjual. Contoh: Caltex serta Pertamina menguasai minyak pelumas.

Ciri- ciri:

1. Ada 2 penjual serta banyak pembeli.

2. Harga didetetapkan secara sepihak oleh kedua penjual

c) Pasar oligopoli,

ialah pasar yang dikuasai oleh beberapa penjual. Contoh: Honda, Suzuki, Yamaha, serta Kawasaki menguasai sepeda motor.

Ciri- ciri:

1. Ada sebagian penjual serta banyak pembeli

2. Barang yang diperjualbelikan bersifat homogeny

3. Ada hambatan untuk penjual baru

4. Adanya saling ketergantungan

5. Pemakaian iklan sangat intensif

d) Pasar monopolistik, ialah pasar dimana ada banyak produsen yang menjual barang yang sama namun dengan berbagai macam variasi.

Ciri- ciri:

1. Ada banyak produsen

2. Barang yang diperjualbelikan sama namun dengan bermacam berbagai variasi

3. Terdapatnya kemudahan untuk produsen baru untuk menawarkan produknya

4. Selalu terbuka kesempatan untuk menghasilkan persaingan

e) Pasar monopsoni, ialah pasar dimana ada banyak penjual namun pembelinya hanya satu. Ciri- ciri:

1. Ada banyak produsen 
2. Pembeli hanya satu

3. Para produsen bersaing keras untuk membagikan pelayanan serta harga serendah mungkin

\section{B. Konsep Pemasaran}

Pemasaran ialah aspek penting untuk meraih sukses untuk perusahaan akan mengetahui terdapatnya metode serta falsafah yang ikut serta didalamnya.). Konsep pemasaran tersebut terbuat dengan memakai 3 aspek dasar ialah

a. Saluran perencanaan serta aktivitas perusahaan mesti berorientasi pada konsumen/ pasar.

b. Volume penjualan yang menguntungkan harus jadi tujuan perusahaan, serta bukannya volume untuk kepentingan volume itu sendiri.

c. Segala aktivitas pemasaran dalam industri harus dikoordinasikan serta diintegrasikan secara organisasi.

Bagi Swastha serta Irawan,( 2005: 10) mendefinisikan konsep pemasaran suatu falsafah bisnis yang menerangkan kalau pemuasan kebutuhan konsumen ialah ketentuan ekonomi serta sosial untuk kelangsungan hidup perusahaan. Bagian pemasaran pada suatu perusahaan memegang peranan yang sangat berarti dalam rangka menggapai besarnya volume penjualan, sebab dengan tercapainya beberapa volume penjualan yang di idamkan berarti kinerja bagian pemasaran dalam memperkenalkan produk sudah berjalan dengan benar. Penjualan serta pemasaran kerap dikira sama namun sebenarnya berbeda.

Tujuan utama konsep pemasaran merupakan melayani konsumen dengan memperoleh beberapa laba atapun keuntungan, ataupun bisa dimaksud sebagai perbandingan antara pemasukan dengan biaya yang layak. Ini berbeda dengan konsep penjualan yang menitikberatkan pada keinginan perusahaan. Falsafah pendekatan penjualan merupakan memproduksi suatu pabrik, setelah itu meyakinkan konsumen supaya bersedia membelinya. Sebaliknya pendekatan konsep pemasaran menghendaki supaya manajemen memastikan keinginan konsumen terlebih dulu, sehabis itu baru melakukan bagaimana caranya memuaskan. 
Dalam pemasaran ada 6 konsep yang ialah bawah penerapan aktivitas pemasaran suatu organisasi ialah: konsep produksi, konsep produk, konsep penjualan, konsep pemasaran, konsep pemasaran sosial, serta konsep pemasaran global.

\section{Konsep produksinya}

Konsep produksi berpendapat kalau konsumen hendak menyukai produk yang ada dimanamana serta biayanya murah. Konsep ini berorientasi pada produksi dengan mengerahkan segenap upaya buat menggapai efesiensi produk besar serta distribusi yang luas. Disini tugas manajemen merupakan memproduksi barang sebanyak mungkin, sebab konsumen dikira akan menerima produk yang ada secara luas dengan daya beli mereka.

\section{Konsep produk}

Konsep produk mengatakan kalau konsumen akan menggemari produk yang menawarkan kualitas, performansi serta ciri- ciri yang terbaik. Tugas manajemen disini ialah membuat produk bermutu, sebab konsumen dianggap menggemari produk bermutu tinggi dalam penampilan dengan karakteristik- karakteristik terbaik.

\section{Konsep penjualan}

Konsep penjualan berpendapat bahwa konsumen, dengan dibiarkan begitu saja, organisasi wajib melakukan upaya penjualan serta promosi yang agresif.

\section{Konsep pemasaran}

Konsep pemasaran mengatakan kalau kunci untuk menggapai tujuan organisasi terdiri dari penentuan kebutuhan serta kemauan pasar sasaran dan memberikan kepuasan yang diharapkan secara lebih efisien serta efektif dibanding para pesaing.

\section{Konsep pemasaran social}

Konsep pemasaran sosial berpendapat kalau tugas organisasi yakni menentukan kebutuhan, kemauan serta kepentingan pasar sasaran dan memberikan kepuasan yang diharapkan dengan metode yang lebih efisien serta efektif daripasda para pesaing dengan senantiasa melestarikan ataupun menaikkan kesejahteraan konsumen serta masyarakat.

\section{Konsep Pemasaran Global}


Pada konsep pemasaran global ini, manajer eksekutif berupaya memahami seluruh faktoraspek lingkungan yang mempengaruhi pemasaran lewat manajemen strategis yang mantap. tujuan akhirnya yaitu berupaya untuk memenuhi keinginan seluruh pihak yang ikut serta dalam industri.

7. Konsep Pemasaran Inti
a) Pasar sasaran serta segmentasi
b) Tempat pasar, ruang pasar, serta metamarket
c) Pemasar serta calon pelanggan
d) Kebutuhan, kemauan, dan permintaan
e) Produk, tawaran, serta merek
f) Nilai serta kepuasan gram) Pertukaran dan transaksi
g) Relasional serta jaringan kerja
h) Saluran pemasaran
i) Rantai pasokan
j) Persaingan
k) Lingkungan pemasaran
1) Program pemasaran

\section{Strategi Pemasaran}

Strategi pemasaran ialah pengambilan keputusan- keputusan tentang bayaran pemasaran, bauran pemasaran, alokasi pemasaran dalam jalinan dengan keadaan area yang diharapkan dan kondisi persaingan. Dalam strategi pemasaran, ada 3 aspek utama yang memunculkan terjadinya perubahan strategi dalam pemasaran yakni:

a. Daur hidup suatu produk

Strategi harus disesuaikan dengan tahap- sesi daur hidup, yakni tahap perkenalan, tahap pertumbuhan, tahap kedewasaan dan tahap kemunduran.

b. Posisi persaingan perusahaan di pasar

Strategi pemasaran harus disesuaikan dengan posisi perusahaan dalam persaingan, apakah memimpin, menantang, mengikuti maupun hanya mengambil sebagian kecil dari pasar.

c. Suasana ekonomi 
Strategi pemasaran harus disesuaikan dengan suasana ekonomi dengan pemikiran kedepan, apakah ekonomi terletak dalam suasana makmur maupun inflasi tinggi. Strategi pemasaran didasarkan atas 5( lima) konsep strategi sebagai berikut:

1. Segmentasi Pasar

Masing- masing pasar terdiri dari bermacam- macam pembeli yang mempunyai kebutuhan dan Kerutinan yang berbeda. Perusahaan tidak mungkin dapat penuhi kebutuhan segala pembeli. Karena itu, industri wajib mengelompokkan pasar yang bersifat heterogen tersebut kedalam satuan- satuan pasar yang bersifat homogen.

2. Market Positioning

Perusahaan tidak mungkin dapat memahami pasar secara keseluruhan, sampai prinsip strategi pemasaran yang kedua ialah memilih pola khusus pasar perusahaan yang hendak memberikan kesempatan maksimum kepada perusahaan untuk mendapatkan peran yang kuat. Dengan kata lain industri wajib memilah segmen pasar yang akan menghasilkan penjualan dan laba sangat besar.

Segmen pasar semacam ini memiliki 4( empat) karakteristik, yakni:

- Berukuran cukup besar

- Mempunyai keahlian untuk berkembang terus

- Tidak memiliki maupun dipadati oleh perusahaan saingan

- Mempunyai kebutuhan yang belum terpenuhi, yang mana kebutuhan tersebut dapat dipuaskan oleh perusahaan yang memilah segmen pasar tersebut.

\section{Market Entry Strategy}

Market entry Strategy ialah strategi industri untuk memasuki segmen pasar yang dijadikan pasar sasaran penjualan.

Strategi memasuki suatu segmen pasar dapat dicoba dengan tata cara:

- Membeli industri lain

Tata cara ini yakni tata cara yang sangat mudah dan cepat, tata cara ini ditempuh apabila:

- Perusahaan pembeli tidak mengidentifikasi tentang seluk beluk industri dari industri yang dibeli

- Sangat menguntungkan buat sedini bisa jadi memasuki segmen pasar yang dipahami perusahaan yang dibeli. 
- Perusahaan hadapi macam- berbagai penghalang buat merambah segmen pasar yang bersangkutan melalui internal development, misalnya patent, economies of scale, saluran distribusi yang sulit dimasuki, bayaran iklan yang mahal maupun kesulitan bahan mentah.

- internal Development

Ada sebagian perusahaan- perusahaan yang lebih suka tumbuh melalui usaha sendiri yakni melalui research and development karena berpendirian jika hanya dengan tata cara inilah kepemimpinan dalam industri dapat dicapai.

- Kerjasama dengan perusahaan lain

Keuntungan dengan tata cara ini ialah jika dampak yang dipikul bersama, dan tiapmasing- masing perusahaan saling memenuhi skill dan resources.

4. Marketing Mix Strategy

Marketing Mix strategy ialah kumpulan variabel- variabel yang dapat dipergunakan perusahaan untuk memepengaruhi anggapan konsumen. Variabel- variabel yang dapat mempengaruhi pembeli ialah yang diucap 7P( product, Price, Place, Promotion, Participant, Prosess, dan People Physical evidence).

5. Timing Strategy

Penentuan disaat yang pas dalam memasarkan benda yakni Mengenai yang perlu dicermati. Meski perusahaan memandang adanya kesempatan baik menetapkan objektif dan menyusun strategy pemasaran, ini tidaklah berarti jika perusahaan dapat segera memulai kegiatan pemasaran. Perusahaan wajib lebih dahulu melakukan persiapan- persiapan baik dibidang produksi maupun dibidang pemasaran, sehabis itu perusahan pula wajib menentukan disaat yang cocok untuk pelemparan barang dan jasa ke pasar.

\section{D.Permintaan dan Penawaran}

\section{- Permintaan}

Permintaan( demand) merupakan banyaknya jumlah barang yang diminta pada sesuatu pasar tertentu dengan tingkatan harga tertentu pada tingkatan i8 tertentu serta dalam periode tertentu( Putong, 2002: 33). Permintaan dalam Islam pastinya memperhatikan syariat yang mengarahkan bahwa kita tidak boleh serakah serta mengeksploitasi suatu secara berlebihan, sebab hendak berakibat kurang baik kepada kita, serta Allah SWT juga tetap tidak menyukai orang- orang yang berlebihan. Pilihan seseorang Muslim dalam perihal 
permintaan dibangun atas kebutuhan akan mashlahah, baik mashlahah yang diterima di dunia maupun di akhirat..

Permintaan dalam Islam menilai suatu komoditas tidak semuanya bisa dikonsumsi maupun digunakan, masih perlu dibedakan antara yang halal dan yang haram. Allah telah berfirman: "Hai orang-orang yang beriman, janganlah kamu haramkan apa - apa yang baik yang telah Allah halalkan bagi kamu, dan janganlah kamu melampaui batas. Sesungguhnya Allah tidak menyukai orang - orang yang melampaui batas. Dan makanlah makanan yang halal lagi baik dari apa yang Allah telah rezekikan kepadamu, dan bertakwalah kepada Allah yang kamu beriman kepadaNya.” (QS. Al-Maidah: 87 - 88)

\section{- Penawaran}

Sebaliknya Penawaran merupakan barang ataupun jasa yang ditawarkan pada jumlah serta tingkatan harga tertentu serta dalam keadaan tertentu. Dalam beberapa hal, terdapat yang membedakan antara penawaran Islam dengan penawaran hedonis, kalau barang ataupun jasa yang ditawarkan harus transparan serta dirinci spesifikasinya, bagaimana kondisi barang tersebut, apa Permintaan serta Penawaran dalam Pengaruhi Pasar.

\section{Aspek yang mempengaruhi permintaan}

Harga barang itu sendiri;

$>$ Harga barang lain yang mempunyai hubungan( barang pengganti ataupun barang pelengkap);

> Pendapatan

selera;Jumlah penduduk; dan

Faktor khusus( akses).

\section{Aspek yang mempengaruhi Penawaran}

Harga benda itu sendiri;

$>$ Harga barang lain yang mempunyai hubungan( barang pengganti ataupun barang pelengkap);

> Teknologi yang digunakan buat mengakses suatu produk;

$>$ Harga input( biaya produksi)

$>$ Tujuan perusahaan; dan

$>$ Faktor khusus( akses). 


\section{E. Segmentasi Pasar}

Segmentasi pasar merupakan suatu strategi yang dilakukan oleh perusahaan untuk membagi kelompok konsumen ke beberapa jenis seperti kebutuhan, ciri ataupun perilaku yang berbeda di dalam suatu pasar tertentu.

\section{Khasiat segmentasi pasar}

Berikut 6 khasiat segmentasi pasar, semacam:

- Ilham pemasaran sesuatu industri lebih terarah

- Menolong industri dalam mengendalikan produknya

- Menolong industri memperoleh pasar segmentasi

- Mempermudah industri buat mengendalikan budget

- Tingkatkan energi tarik konsumen

- Mendapatkan posisi yang menguntungkan.

\section{Jenis- jenis Segmentasi Pasar}

1. Segmentasi perilaku

Segmentasi ini membagi konsumen bagi pengetahuan, loyalitas, reaksi serta pemakaian konsumen terhadap produk ataupun jasa yang Kamu tawarkan. Anda juga sanggup membaginya bagi seberapa manfaat yang diperoleh konsumen. Contohnya, menjual kuas make- up, jalani peningkatan pangkat online Kamu pada posisi yang menjual make- up. ini akan menyimpan Anda kesempatan lebih besar.

2. Segmentasi psikografis

Segmentasi ini membagi konsumen bagi hal yang disukai, kegiatan yang dicoba serta pendapat konsumen. Dengan istilah lain, segmentasi ini serius dalam dimensi psikologis, misalnya hobi serta ketertarikan.

3. Segmentasi demografis 
Strategi ini membagi konsumen bagi karakeristik generik konsumen, semacam umur, gender, pekerjaan, pembelajaran, pemasukan serta yang lain. Segmentasi ini sesungguhnya relatif mudah dicoba lantaran jumlah konsumen. Namun pula relatif susah lantaran pangsa pasarnya sangat luas. Sehingga memerlukan bisnis yang lebih besar serta pembagian yang lebih rinci biar menerima konsumen yang sa 


\section{BAB III}

\section{PENUTUP}

\section{A. Kesimpulan}

pasar dapat diartikan sebagai tempat bertemunya para penjual dan pembeli untuk melakukan transaksi. Pemasaran adalah suatu proses sosial dan manajerial dengan mana individu dan kelompok memperoleh apa yang mereka butuhkan dan inginkan dengan cara menciptakan serta mempertukarkan produk dan nilai dengan pihak lain permintaan adalah keinginan yang didukung oleh daya beli dan akses untuk membeli. Penawaran adalah jumlah suatu barang tertentu yang mau dijual pada berbagai kemungkinan harga, dalam jangka waktu tertentu. Penawaran penawaran barang atau jasa yang dilakukan oleh penjual.segmentasi pasar adalah membagi pasar menjadi beberapa kelompok pembeli berbeda yang mungkin memerlukan barang atau jasa yang berbeda pula.

\section{B. Saran}

Penulis berharap makalah ini dapat menambah wawasan bagi seluruh Mahasiswa khususnya para pembaca agar dapat meningkatkan kualitas Manajemen Pasar dan Pemasaran usahanya, dan dapat menambah pengetahuan bagi rekan-rekan Mahasiswa. Demi penyempurnaan makalah in,kami mengharapkan kritik dan saran.

\section{DAFTAR PUSTAKA}

Algifari. 2002. Ekonomi Mikro, Teori dan Kasus. Edisi Kesatu. Yogyakarta : STIE YKPN. Anoraga, Pandji dan Djoko Sudantoko. 2002. Koperasi, Kewirausahaan, dan Usaha Kecil. Jakarta : Penerbit Rineka Cipta.

Kotler, Philip. 2001. Manajemen Pemasaran di Indonesia : Analisis, Perencanaan, Implementasi dan Pengendalian. Salemba Empat. Jakarta.

M.Fuad, Christine H, Nurlela, Sugiarto, dan Paulus Y.E.F. 2000. Pengantar Bisnis. Jakarta: Gramedia Pustaka Utama. 
Stanton, William J. 2001. Prinsip Pemasaran. Erlangga. Jakarta.

Swastha, Basu dan Irawan. 2005. Manajemen Pemasaran Modern. Liberty : Yogyakarta.

Putong, Iskandar. 2002. Ekonomi Mikro dan Makro, Jakarta: Ghalia Indonesia. Saksono, Widji. 1996. Mengislamkan Tanah Jawa; Telaah atas Metode Dakwah Walisongo, Bandung: Mizan, Cet. 3. 